\title{
An update on clinical oncology for the non-oncologist
}

\author{
Avanços em oncologia para o não oncologista \\ Rafael Aliosha Kaliks ${ }^{1}$
}

\begin{abstract}
Recent advances in the understanding of tumor driver mutations, signaling pathways that lead to tumor progression, and the better understanding of the interaction between tumor cells and the immune system are revolutionizing cancer treatment. The pace at which new treatments are approved and the prices at which they are set have made it even more difficult to offer these treatments in countries like Brazil. In this review we present for the non-oncologist these new treatments and compare their availability in Brazilian public health system and private health system with that of developed countries.
\end{abstract}

Keywords: Neoplasms/trends; Immunotherapy/trends

\section{RESUMO}

Avanços recentes na compreensão de mutações promotoras de desenvolvimento do câncer, sinalização que leva à progressão de tumores, e o avanço no entendimento da interação entre as células tumorais e 0 sistema imunológico estão revolucionando 0 tratamento do câncer. A velocidade com que novos tratamentos são aprovados e 0 alto custo das medicações dificultam a disponibilização de terapêuticas em países como o Brasil. Nesta revisão, apresentamos ao não oncologista esses novos tratamentos e comparamos sua disponibilidade nos sistemas público e privado de saúde no Brasil com os países desenvolvidos.

Descritores: Neoplasias/tendências; Imunoterapia/tendências

\section{INTRODUCTION}

Within the last few years, the field of systemic therapy in medical oncology has seen two dramatic changes. First, the advances in the understanding of genetic abnormalities led to the discovery of various tumor driver mutations with the consequent development of different targeted therapies. Second, the better understanding of interaction between tumor cells and immune system led to the now much broader field of immuno-oncology and the consequent development of immunotherapies, which is currently being tested for treatment of different cancer types. In addition to these advances, a few new traditional chemotherapies have been approved and some already well-known treatments have had their indication broadened. Our objective is to review, for non-oncologists, the most recent advances of modern systemic cancer treatment.

\section{TARGETED THERAPIES}

New technologies developed after the year 2000 allowed progressively more ambitious and thorough evaluation of tumors at molecular level. A major initiative has been the whole genome sequencing of various tumors, launched in 2005 as part of The Cancer Genome Atlas. ${ }^{(1)}$ So far, more than 20 different tumor types have been fully sequenced. The advances in the evaluation of genetic and epigenetic abnormalities and their consequences on the transcriptome have allowed a better understanding and further mapping of an intricate signaling pathway network, which characterizes the hallmarks of cancer cells. $^{(2,3)}$ The identification of driver mutations have crossed histologically driven tumor classifications, leading to a new way of looking at tumors, now based on the mutations rather than histology or organ in which the tumor arises. Although the identification of targets in tumor cells led to the development of various targeted therapies, we are now confronting the fact that these treatments have unfortunately not led to cure in metastatic cancers as once expected, despite the fact that outcomes such as progression free survival and overall

\footnotetext{
1 Hospital Israelita Albert Einstein, São Paulo, SP, Brazil.

Corresponding author: Rafael Aliosha Kaliks - Avenida Albert Einstein, 627/701 - Morumbi - Zip code: 05652-900 - São Paulo, SP, Brazil - Phone: (55 11) 2151-1648 - E-mail: rkaliks@einstein.br Received on: Sep 14, 2015 - Accepted on: Nov 13, 2015
}

DOI: 10.1590/\$1679-45082016MD3550 
survival have improved. In addition, before choosing the therapies, it is necessary to test the target, which sometimes requires sophisticated and costly techniques. Considering that some targets may be present in less than 5 to $10 \%$ of the patient population, many of them need to be tested in order to find one eligible for the targeted treatment. Adding the costs of tests and the drugs, these therapies are almost prohibitive for the Brazilian Public Health System, which prevent a significant majority of our population from receiving such treatments.

Table 1 shows selected new targeted therapies made available in the last three years. Approval in Brazil has been limited, mainly due to regulatory delays, but

Table 1. Targeted therapies

\begin{tabular}{|c|c|c|c|c|c|c|}
\hline Reference & $\begin{array}{l}\text { Tumor type } \\
\text { (by organ) }\end{array}$ & Name of drug & Mechanism of action & Indication & Main results & Availability in Brazil \\
\hline Verma et al. ${ }^{(4)}$ & Breast & $\begin{array}{l}\text { Ado-trastuzumab } \\
\text { emtansine } \\
\text { (T-DM1) }\end{array}$ & $\begin{array}{l}\text { Antibody-drug conjugate } \\
\text { against Her2+ cells }\end{array}$ & $\begin{array}{c}\text { Metastatic Her2+ breast cancer, } \\
\text { after failing trastuzumab and } \\
\text { taxane }\end{array}$ & $\begin{array}{l}\text { Improved PFS and overall } \\
\text { survival compared with } \\
\text { lapatinib and capecitabine }\end{array}$ & $\begin{array}{l}\text { Registered in Brazil. Not } \\
\text { available in Brazilian Public } \\
\text { Health System }\end{array}$ \\
\hline Swain et al. ${ }^{(5)}$ & Breast & Pertuzumab & Her2 inhibition & Metastatic Her $2+$ breast cancer & $\begin{array}{l}\text { Improved PFS and overall } \\
\text { survival compared with } \\
\text { trastuzumab and taxane }\end{array}$ & $\begin{array}{c}\text { Registered in Brazil. Not } \\
\text { available in Brazilian Public } \\
\text { Health System }\end{array}$ \\
\hline Piccart et al. ${ }^{[6]}$ & Breast & Everolimus & mTOR inhibitor & $\begin{array}{c}\text { Metastatic HR+ and Her2- breast } \\
\text { cancer in combination with } \\
\text { exemestane }\end{array}$ & $\begin{array}{l}\text { Improved PFS compared with } \\
\text { second line exemestane alone }\end{array}$ & $\begin{array}{c}\text { Registered in Brazil. Not } \\
\text { available in Brazilian Public } \\
\text { Health System }\end{array}$ \\
\hline Turner et al. ${ }^{(7)}$ & Breast & Palbociclib & CDK4 and CDK6 inhibitor & $\begin{array}{l}\text { Metastatic } \mathrm{HR}+\text { and Her2- breast } \\
\text { cancer in combination with } \\
\text { fulvestrant }\end{array}$ & $\begin{array}{l}\text { Improved PFS compared with } \\
\text { second line Fulvestrant alone }\end{array}$ & Not registered in Brazil \\
\hline Tewari et al. ${ }^{|8|}$ & Cervix & Bevacizumab & VEGF inhibitor & Metastatic cervical cancer & $\begin{array}{l}\text { Improved overall survival when } \\
\text { added to chemotherapy }\end{array}$ & $\begin{array}{l}\text { Registered in Brazil. Not } \\
\text { available in the Brazilian } \\
\text { Public Health System }\end{array}$ \\
\hline Grothey et al..$^{(9)}$ & Colorectal & Regorafenib & Multikinase inhibitor & $\begin{array}{l}\text { Previously treated metastatic } \\
\text { colorectal cancer }\end{array}$ & $\begin{array}{l}\text { Modest improvement in } \\
\text { overall survival compared with } \\
\text { supportive care alone }\end{array}$ & Not registered in Brazil \\
\hline Fuchs et al. ${ }^{(10)}$ & Gastric & Ramucirumab & VEGFR2 antagonist & $\begin{array}{c}\text { Inoperable gastric or } \\
\text { gastroesophageal junction } \\
\text { adenocarcinoma after prior } \\
\text { chemotherapy }\end{array}$ & $\begin{array}{l}\text { Improved survival compared } \\
\text { with placebo }\end{array}$ & Not registered in Brazil \\
\hline Demetri et al.!11) & GIST & Regorafenib & Multikinase inhibitor & $\begin{array}{c}\text { Metastatic GIST after standard } \\
\text { treatment with imatinib and } \\
\text { sunitinib }\end{array}$ & $\begin{array}{l}\text { Improved PFS compared } \\
\text { with placebo }\end{array}$ & Not registered in Brazil \\
\hline $\begin{array}{l}\text { Wu et al. } .^{(12)} \text {; } \\
\text { Sequist et al. }{ }^{(13)}\end{array}$ & Lung & Afatinib & EGFR inhibitor & $\begin{array}{l}\text { Metastatic NSCLC with } \\
\text { EGFR exon } 19 \text { deletion or } \\
\text { L858R EGFR mutation }\end{array}$ & $\begin{array}{l}\text { Improved PFS compared with } \\
\text { gemcitabine and cisplatin or } \\
\text { with cisplatin and pemetrexed }\end{array}$ & Not registered in Brazil \\
\hline Shaw et al. ${ }^{(14,15)}$ & Lung & Crizotinib & ALK inhibitor, ROS1 inhibitor & $\begin{array}{l}\text { Metastatic NSCLC with } \\
\text { ALK-EML4 fusion, or with } \\
\text { ROS1 rearrangement }\end{array}$ & $\begin{array}{l}\text { Improved PFS compared } \\
\text { with pemetrexed in platinum } \\
\text { refractory disease }\end{array}$ & Not registered in Brazil \\
\hline Shaw et al.!16) & Lung & Ceritinib & ALK inhibitor & $\begin{array}{c}\text { Metastatic ALK-rearranged } \\
\text { NSCLC }\end{array}$ & $\begin{array}{l}\text { Responses in naïve and } \\
\text { crizotinib pretreated disease }\end{array}$ & Not registered in Brazil \\
\hline $\begin{array}{l}\text { Chapman } \\
\text { et al.!17) }\end{array}$ & Melanoma & Vemurafenib & BRAF inhibitor & $\begin{array}{l}\text { Metastatic melanoma with } \\
\text { BRAF V600E mutation }\end{array}$ & $\begin{array}{l}\text { Improved overall survival } \\
\text { and PFS compared with } \\
\text { Dacarbazine }\end{array}$ & $\begin{array}{l}\text { Registered in Brazil. Not } \\
\text { available in the Brazilian } \\
\text { Public Health System }\end{array}$ \\
\hline Robert et al. ${ }^{(18)}$ & Melanoma & Dabrafenib & BRAF inhibitor & $\begin{array}{l}\text { Metastatic melanoma BRAF } \\
\text { V600E mutation }\end{array}$ & $\begin{array}{l}\text { Improved overall survival when } \\
\text { combined with Trametinib, } \\
\text { compared with Vemurafenib }\end{array}$ & Not registered in Brazil. \\
\hline Robert et al. ${ }^{(18)}$ & Melanoma & Trametinib & MEK inhibitor & $\begin{array}{l}\text { Metastatic Melanoma with BRAF } \\
\text { V600E or V600K mutation }\end{array}$ & $\begin{array}{l}\text { Improved overall survival when } \\
\text { combined with Dabrafenib, } \\
\text { compared with Vemurafenib }\end{array}$ & Not registered in Brazil \\
\hline $\begin{array}{l}\text { Ledermann } \\
\text { et al. } .^{(19)}\end{array}$ & Ovary & Olaparib & $\begin{array}{l}\text { Inhibitor of poly (ADP-ribose) } \\
\text { polymerase }\end{array}$ & $\begin{array}{l}\text { BRCA mutated advanced } \\
\text { ovarian cancer }\end{array}$ & $\begin{array}{l}\text { Improved PFS compared } \\
\text { with placebo in platinum } \\
\text { sensitive relapse }\end{array}$ & Not registered in Brazil \\
\hline Brose et al. ${ }^{(20)}$ & Thyroid & Sorafenib & Multi-kinase inhibitor & $\begin{array}{l}\text { Metastatic differentiated } \\
\text { thyroid cancer refractory to } \\
\text { radioactive iodine }\end{array}$ & $\begin{array}{l}\text { Improved PFS compared } \\
\text { with placebo }\end{array}$ & $\begin{array}{l}\text { Not registered in Brazil for } \\
\text { this indication }\end{array}$ \\
\hline
\end{tabular}


...Continuation

Table 1. Targeted therapies

\begin{tabular}{|c|c|c|c|c|c|c|}
\hline Reference & $\begin{array}{l}\text { Tumor type } \\
\text { (by organ) }\end{array}$ & Name of drug & Mechanism of action & Indication & Main results & Availability in Brazil \\
\hline $\begin{array}{l}\text { Schlumberger } \\
\text { et al. } .^{(21)}\end{array}$ & Thyroid & Lenvatinib & $\begin{array}{l}\text { VEGF receptor inhibitor, } \\
\text { PDGFR inhibitor, RET and KIT }\end{array}$ & $\begin{array}{l}\text { Metastatic differentiated } \\
\text { thyroid cancer refractory to } \\
\text { radioactive iodine }\end{array}$ & $\begin{array}{l}\text { Improved PFS compared } \\
\text { with placebo }\end{array}$ & Not registered in Brazil \\
\hline Elisei et al. ${ }^{(22)}$ & $\begin{array}{l}\text { Medullary } \\
\text { thyroid }\end{array}$ & Cabozantinib & $\begin{array}{l}\text { MET, VEGFR2 and RET } \\
\text { inhibitor }\end{array}$ & $\begin{array}{l}\text { Progressive metastatic } \\
\text { medullary thyroid cancer }\end{array}$ & $\begin{array}{l}\text { Improved PFS compared } \\
\text { with placebo }\end{array}$ & Not registered in Brazil \\
\hline Wells et al. ${ }^{(23)}$ & $\begin{array}{l}\text { Medullary } \\
\text { thyroid }\end{array}$ & Vandetanib & $\begin{array}{l}\text { RET kinase inhibitor and } \\
\text { VEGF inhibitor }\end{array}$ & $\begin{array}{l}\text { Progressive metastatic } \\
\text { medullary thyroid cancer }\end{array}$ & $\begin{array}{l}\text { Improved PFS compared } \\
\text { with placebo }\end{array}$ & Not registered in Brazil \\
\hline
\end{tabular}

T-DM1: Kadcyla; Her2: human epidermal growth factor receptor 2; PFS: progression-free survival; CDK: cyclin-dependent kinase; VEGF: vascular endothelial growth factor; VEGFR: vascular endothelial growth factor receptor; GIST: gastrointestinal stromal tumor; EGFR: epidermal growth factor receptor; NSCLC: non small cell lung cancer; ALK: anaplastic lymphoma kinase; ROS1: ROS proto-oncogene 1; BRAF: proto-oncogene B-Raf; MEK: mitogen activated protein kinase; BRCA: breast cancer gene; PDGFR: platelet derived growth factor receptor; MET: hepatocyte growth factor receptor; RET: rearranged during transfection; KIT: proto-oncogene c-Kit.

certainly influenced by costs as well. The table describes the main indications, the targets for each drug and the most important outcomes reported in clinical trials.

Some targeted therapies that have been approved and made available in the private health system in Brazil for several years still have limited access in the Brazilian Public Health System. Some examples are trastuzumab for metastatic Her2+ breast cancer; erlotinib and gefitinib for epidermal growth factor receptor (EGFR) mutated metastatic lung cancer; cetuximab and panitumumab for RAS-wild type metastatic colorectal cancer, in addition to several treatments used in hematological malignancies, which are not the focus of this report. Some other targeted treatments have been available for several years in North America and/or Europe, but they are still not registered in Brazil. Examples are aflibercept for colorectal cancer, pazopanib and trabectedine for soft tissue sarcomas, and axitinib for renal cell carcinoma.

\section{IMIMUNOTHERAPY}

Human immune system has been known for quite some time for recognizing tumor antigens and mounting an immune response, although the actual explanation for the variability in tumor control by the immune system remains elusive. Cancer cells are capable of evading the immune surveillance by suppressing tumordirected immunity through mechanisms described over the last two decades. ${ }^{(24)}$ It occurs by inhibiting helper and cytotoxic $\mathrm{T}$ cells while stimulating regulatory $\mathrm{T}$ cells instead. Inhibitory mechanisms determined by cytotoxic T-lymphocyte-associated antigen-4 (CTLA-4), programmed death 1 (PD1) and its ligand programmed death ligand 1 (PD-L1) can currently be targeted and inhibited by new immunotherapies, which lead to unblocking the immune response. This will ultimately unleash an immune attack on cancer cells. Anti-CTLA-4 antibodies as well as PD1 and PD-L1 inhibitors are already approved and used to treat a limited number of tumor types (melanoma and lung cancer), and promising preliminary results indicate potential future use in a large variety of cancers.

Table 2 outlines the new immunotherapies, its approved indications, mechanism of action and main results in clinical trials.

The successful combination of two immunotherapies was already reported. Combined nivolumab and ipilimumab had better results than either drug alone to treat metastatic melanoma. ${ }^{(32,33)}$ Both nivolumab and pembrolizumab, as well as other anti-PD1, anti PD-L1 and combinations with anti-CTLA-4, are under test for a variety of tumors, with some extraordinary preliminary results. Positive results with these immunotherapies have been reported in kidney, bladder, pancreatic, metastatic colorectal cancer related to Lynch syndrome, gastroesophageal cancer and glioblastoma, among others. Of note, although, is that for most diseases exist a clear correlation of benefit with the higher expression of PD-L1 on tumor cells, ${ }^{(34,35)}$ and there is still no standardized evaluation for the expression of PD1 or PD-L1. An unique aspect related to immunotherapies is sometimes the significant delayed response, which has been reported both with anti-CTLA-4 as well as anti-PD1 inhibitors. ${ }^{(36,37)}$ This highlights the need for careful consideration before deeming these drugs ineffective, and it has led to the establishment of a different set of response criteria, known as immune-related response criteria (irRC). ${ }^{(38)}$ Immune related adverse events derive from the activation of autoimmune-mediated diseases in the skin, gastrointestinal tract, liver and endocrine system. The most clinically relevant adverse 
Table 2. Immunotherapies

\begin{tabular}{|c|c|c|c|c|c|c|}
\hline Reference & $\begin{array}{l}\text { Tumor type } \\
\text { (by organ) }\end{array}$ & Name of drug & $\begin{array}{l}\text { Mechanism of } \\
\text { action }\end{array}$ & Indication & Main results & Availability in Brazil \\
\hline $\begin{array}{l}\text { Hodi et al. }{ }^{(25)} ; \\
\text { Robert et al. }\end{array}$ & Melanoma & Ipilimumab & Anti-CTLA-4 & Metastatic melanoma & $\begin{array}{l}\text { Improved overall survival compared with } \\
\text { gp100 vaccine and improved overall } \\
\text { survival when added to dacarbazine } \\
\text { compared with dacarbazine alone }\end{array}$ & $\begin{array}{l}\text { Registered in Brazil. Not } \\
\text { available in the Brazilian } \\
\text { Public Health System }\end{array}$ \\
\hline $\begin{array}{l}\text { Robert et al. }{ }^{(27)} \mathrm{e} \\
\text { Weber et al. }{ }^{(28)}\end{array}$ & Melanoma & Nivolumab & Anti-PD1 & $\begin{array}{l}\text { Metastatic melanoma } \\
\text { without BRAF mutation } \\
\text { or after progression on } \\
\text { Ipilimumab and BRAF } \\
\text { inhibitor }\end{array}$ & $\begin{array}{l}\text { Improved overall survival and progression } \\
\text { free survival compared with dacarbazine }\end{array}$ & Not registered in Brazil \\
\hline Robert et al. ${ }^{(29)}$ & Melanoma & Pembrolizumab & Anti-PD1 & Metastatic melanoma & $\begin{array}{l}\text { Improved overall survival and progression } \\
\text { free survival compared with ipilimumab }\end{array}$ & Not registered in Brazil \\
\hline Brahmer et al. ${ }^{(30)}$ & Lung & Nivolumab & Anti-PD1 & $\begin{array}{l}\text { Metastatic NSCLC, } \\
\text { squamous histology }\end{array}$ & $\begin{array}{l}\text { Improved overall survival, progression } \\
\text { free survival and response rate } \\
\text { compared with Docetaxel }\end{array}$ & Not registered in Brazil \\
\hline Garon et al..$^{\mid 31\}}$ & Lung & Pembrolizumab & Anti-PD1 & Metastatic NSCLC & Significant antitumor activity & Not registered in Brazil \\
\hline
\end{tabular}

CTLA-4: cytotoxic T-lymphocyte-associated antigen-4; PD1: programmed death 1; BRAF: proto-oncogene B-Raf; NSCLC: non small cell lung cancer.

event is diarrhea, which may have late onset and be life threatening if not rapidly and properly treated.

\section{OTHER NEW SYSTEMIC TREATMENTS}

In addition to the new targeted therapies and immunotherapies, few other new treatments (with various mechanisms of action) with significant clinical impact have emerged and been approved for clinical use in recent years.

Table 3 describes new systemic treatments, its indications, mechanisms of action and main results in clinical trials.
There is currently a very vivid discussion around the world about the significant costs associated with new cancer therapy in general, and specifically about anticancer drugs. Immunotherapies, which seem to be on their way to become indicated for a large proportion of cancer patients, and some of the newer targeted therapies can cost hundreds of thousands of dollars per patient annually. ${ }^{(45)}$ Cost is certainly a significant limiting factor for these drugs becomes available in Brazil.

Some good cancer treatments are still under registration process in Brazil, highlighting the gap between what is practice here in comparison with developed countries. No less important is the significant

Table 3. Other new cancer therapies

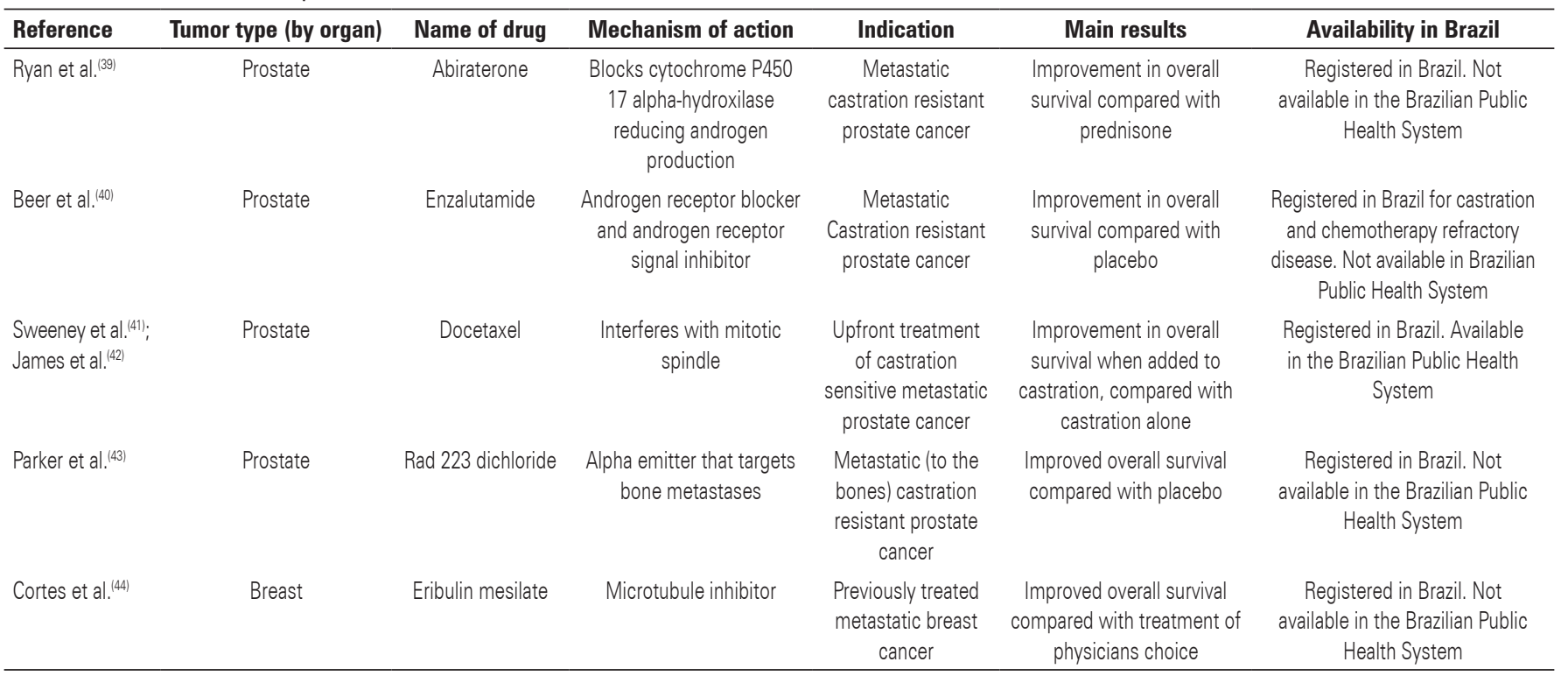


difference between what is registered and used in the private health system and what is available and used in the Brazilian public health system. Unless pricing of drugs becomes more reasonable in the near future, and unless health technology evaluation for the public health system starts to be dictated by well-established standards and pre-specified cost-effectiveness limits, new cancer therapies will be ever more limited in developing countries like Brazil, and as a consequence the difference between what is practiced internationally and in our country will widen significantly.

\section{REFERENCES}

1. National Cancer Institute. National Human Genome Research Institute. The cancer genome atlas [Internet]. Bethesda: NCT [cited 2015 Sep 12]. Available from: http://cancergenome.nih.gov/publications

2. Hanahan D, Weinberg RA. The hallmarks of cancer. Cell. 2000;100(1):57-70. Review.

3. Hanahan D, Weinberg RA. Hallmarks of cancer: the next generation. Cell. 2011;144(5):646-74. Review.

4. Verma S, Miles D, Gianni L, Krop IE, Welslau M, Baselga J, Pegram M, Oh DY, Diéras V, Guardino E, Fang L, Lu MW, Olsen S, Blackwell K; EMILIA Study Group. Trastuzumab emtansine for HER2-positive advanced breast cancer. N Engl J Med. 2012;367(19):1783-91. Erratum in: N Engl J Med. 2013; 368(25):2442.

5. Swain SM, Baselga J, Kim SB, Ro J, Semiglazov V, Campone M, Ciruelos E, Ferrero JM, Schneeweiss A, Heeson S, Clark E, Ross G, Benyunes MC, Cortés J; CLEOPATRA Study Group. Pertuzumab, trastuzumab, and docetaxel in HER2-positive metastatic breast cancer. N Engl J Med. 2015;372(8):724-34.

6. Piccart $\mathrm{M}$, Hortobagyi $\mathrm{GN}$, Campone $\mathrm{M}$, Pritchard $\mathrm{Kl}$, Lebrun $\mathrm{F}$, Ito $\mathrm{Y}$, et al. Everolimus plus exemestane for hormone-receptor-positive, human epidermal growth factor receptor-2-negative advanced breast cancer: overall survival results from BOLERO-2†. Ann Oncol. 2014;25(12):2357-62.

7. Turner NC, Ro J, André F, Loi S, Verma S, Iwata H, Harbeck N, Loibl S, Huang Bartlett C, Zhang K, Giorgetti C, Randolph S, Koehler M, Cristofanilli M; PALOMA3 Study Group. Palbociclib in Hormone-Receptor-Positive Advanced Breast Cancer. N Engl J Med. 2015;373(3):209-19.

8. Tewari KS, Sill MW, Long HJ 3rd, Penson RT, Huang H, Ramondetta LM, et al. Improved survival with bevacizumab in advanced cervical cancer. N Engl J Med. 2014;370(8):734-43

9. Grothey A, Van Cutsem E, Sobrero A, Siena S, Falcone A, Ychou M, Humblet Y, Bouché O, Mineur L, Barone C, Adenis A, Tabernero J, Yoshino T, Lenz HJ, Goldberg RM, Sargent DJ, Cihon F, Cupit L, Wagner A, Laurent D; CORRECT Study Group. Regorafenib monotherapy for previously treated metastatic colorectal cancer (CORRECT): an international, multicentre, randomised, placebocontrolled, phase 3 trial. Lancet. 2013;381(9863):303-12.

10. Fuchs CS, Tomasek J, Yong CJ, Dumitru F, Passalacqua R, Goswami C, Safran H, dos Santos LV, Aprile G, Ferry DR, Melichar B, Tehfe M, Topuzov E, Zalcberg JR, Chau I, Campbell W, Sivanandan C, Pikiel J, Koshiji M, Hsu Y, Liepa AM, Gao L, Schwartz JD, Tabernero J; REGARD Trial Investigators. Ramucirumab monotherapy for previously treated advanced gastric or gastro-oesophageal junction adenocarcinoma (REGARD): an international, randomised, multicentre, placebo-controlled, phase 3 trial. Lancet. 2014;383(9911):31-9.

11. Demetri GD, Reichardt $P$, Kang YK, Blay JY, Rutkowski P, Gelderblom $H$, Hohenberger $\mathrm{P}$, Leahy $\mathrm{M}$, von Mehren $\mathrm{M}$, Joensuu $\mathrm{H}$, Badalamenti $\mathrm{G}$, Blackstein M, Le Cesne A, Schöffski P, Maki RG, Bauer S, Nguyen BB, Xu J, Nishida T, Chung J, Kappeler C, Kuss I, Laurent D, Casali PG; GRID study investigators. Efficacy and safety of regorafenib for advanced gastrointestinal stromal tumours after failure of imatinib and sunitinib (GRID): an international, multicentre, randomised, placebo-controlled, phase 3 trial. Lancet. 2013; 381(9863):295-302.

12. Wu YL, Zhou C, Feng J, Lu S, Huang Y, Li W, et al. Afatinib versus cisplatin plus gemcitabine for first-line treatment of Asian patients with advanced non-smallcell lung cancer harbouring EGFR mutations (LUX-Lung 6): an open-label, randomised phase 3 trial. Lancet Oncol. 2014;15(2):213-22.

13. Sequist LV, Yang JC, Yamamoto N, $O^{\prime}$ Byrne K, Hirsh V, Mok T, et al. Phase III study of afatinib or cisplatin plus pemetrexed in patients with metastatic lung adenocarcinoma with EGFR mutations. J Clin Oncol. 2013;31(27):3327-34.

14. Shaw AT, Kim DW, Nakagawa K, Seto T, Crinó L, Ahn MJ, et al. Crizotinib versus chemotherapy in advanced ALK-positive lung cancer. N Engl J Med. 2013;368(25):2385-94

15. Shaw AT, Ou SH, Bang YJ, Camidge DR, Solomon BJ, Salgia R, et al. Crizotinib in ROS1-rearranged non-small-cell lung cancer. N Engl J Med. 2014;371(21): 1963-71.

16. Shaw AT, Kim DW, Mehra R, Tan DS, Felip E, Chow LQ, et al. Ceritinib in ALK rearranged non-small-cell lung cancer. N Engl J Med. 2014;370(13):1189-97.

17. Chapman PB, Hauschild A, Robert C, Haanen JB, Ascierto P, Larkin J, Dummer R, Garbe C, Testori A, Maio M, Hogg D, Lorigan P, Lebbe C, Jouary T, Schadendorf D, Ribas A, O'Day SJ, Sosman JA, Kirkwood JM, Eggermont AM, Dreno B, Nolop K, Li J, Nelson B, Hou J, Lee RJ, Flaherty KT, McArthur GA; BRIM-3 Study Group. Improved survival with vemurafenib in melanoma with BRAF V600E mutation. N Engl J Med. 2011;364(26):2507-16.

18. Robert C, Karaszewska B, Schachter J, Rutkowski P, Mackiewicz A, Stroiakovski $D$, et al. Improved overall survival in melanoma with combined dabrafenib and trametinib. N Engl J Med. 2015;372(1):30-9.

19. Ledermann J, Harter P, Gourley C, Friedlander M, Vergote I, Rustin G, et al Olaparib maintenance therapy in patients with platinum-sensitive relapsed serous ovarian cancer: a preplanned retrospective analysis of outcomes by BRCA status in a randomised phase 2 trial. Lancet Oncol. 2014;15(8):852-61. Erratum in: Lancet Oncol. 2015;16(4):e158.

20. Brose MS, Nutting CM, Jarzab B, Elisei R, Siena S, Bastholt $L$, de la Fouchardiere C, Pacini F, Paschke R, Shong YK, Sherman SI, Smit JW, Chung J, Kappeler C, Peña C, Molnár I, Schlumberger MJ; DECISION investigators. Sorafenib in radioactive iodine-refractory, locally advanced or metastatic differentiated thyroid cancer: a randomised, double-blind, phase 3 trial. Lancet. 2014;384(9940):319-28.

21. Schlumberger M, Tahara M, Wirth LJ, Robinson B, Brose MS, Elisei R, et al. Lenvatinib versus placebo in radioiodine-refractory thyroid cancer. N Engl J Med. 2015;372(7):621-30.

22. Elisei R, Schlumberger MJ, Müller SP, Schöffski P, Brose MS, Shah MH, et al. Cabozantinib in progressive medullary thyroid cancer. J Clin Oncol. 2013; 31(29):3639-46. Erratum in: J Clin Oncol. 2014;32(17):1864.

23. Wells SA Jr, Robinson BG, Gagel RF, Dralle H, Fagin JA, Santoro M, et al Vandetanib in patients with locally advanced or metastatic medullary thyroid cancer: a randomized, double-blind phase III trial. J Clin Oncol. 2012;30(2): 134-41. Erratum in: J Clin Oncol. 2013;31(24):3049.

24. Ribas A. Releasing the brakes on Cancer Immunotherapy. N Eng J Med. 2015;373(16):1490-2

25. Hodi FS, O'Day SJ, McDermott DF, Weber RW, Sosman JA, Haanen JB, et al Improved survival with ipilimumab in patients with metastatic melanoma. N Engl J Med. 2010;363(8):711-23. Erratum in: N Engl J Med. 2010;363(13):1290.

26. Robert C, Thomas L, Bondarenko I, O'Day S, Weber J, Garbe C, et al. Ipilimumab plus dacarbazine for previously untreated metastatic melanoma. N Engl J Med. 2011;364(26):2517-26

27. Robert C, Long GV, Brady B, Dutriaux C, Maio M, Mortier L, et al. Nivolumab in previously untreated melanoma without BRAF mutation. N Engl J Med. 2015;372(4):320-30

28. Weber JS, D'Angelo SP, Minor D, Hodi FS, Gutzmer R, Neyns B, et al. Nivolumab versus chemotherapy in patients with advanced melanoma who progressed after anti-CTLA-4 treatment (CheckMate 037): a randomised, controlled, open-label, phase 3 trial. Lancet Oncol. 2015;16(4):375-84. 
29. Robert C, Schachter J, Long GV, Arance A, Grob JJ, Mortier L, Daud A, Carlino MS, McNeil C, Lotem M, Larkin J, Lorigan P, Neyns B, Blank CU, Hamid O, Mateus C, Shapira-Frommer R, Kosh M, Zhou H, Ibrahim N, Ebbinghaus S, Ribas A; KEYNOTE-006 investigators. Pembrolizumab versus Ipilimumab in Advanced Melanoma. N Engl J Med. 2015;372(26):2521-32.

30. Brahmer J, Reckamp KL, Baas P, Crinò L, Eberhardt WE, Poddubskaya E, et al. Nivolumab versus Docetaxel in Advanced Squamous-Cell Non-Small-Cell Lung Cancer. N Engl J Med. 2015;373(2):123-35.

31. Garon EB, Rizvi NA, Hui R, Leighl N, Balmanoukian AS, Eder JP, Patnaik A, Aggarwal C, Gubens M, Horn L, Carcereny E, Ahn MJ, Felip E, Lee JS, Hellmann MD, Hamid O, Goldman JW, Soria JC, Dolled-Filhart M, Rutledge RZ, Zhang J, Lunceford JK, Rangwala R, Lubiniecki GM, Roach C, Emancipator K, Gandhi L; KEYNOTE-001 Investigators. Pembrolizumab for the treatment of non-small-cell lung cancer. N Engl J Med. 2015;372(21):2018-28.

32. Wolchok JD, Kluger H, Callahan MK, Postow MA, Rizvi NA, Lesokhin AM, et al. Nivolumab plus ipilimumab in advanced melanoma. N Engl J Med. 2013; 369(2):122-33.

33. Larkin J, Chiarion-Sileni V, Gonzalez R, Grob JJ, Cowey CL, Lao CD, et al. Combined Nivolumab and Ipilimumab or Monotherapy in Untreated Melanoma. N Engl J Med. 2015;373(1):23-34.

34. Grosso J, Horak CE, Inzunza D, Cardona DM, Simon JS, Gupta AK, et al. Association of tumor PD-L1 expression and immune biomarkers with clinical activity in patients (pts) with advanced solid tumors treated with nivolumab (antiPD-1; BMS-936558; 0NO-4538) [abstract]. J Clin Oncol. 2013;31(Suppl abstract 3016).

35. Topalian SL, Hodi FS, Brahmer JR, Gettinger SN, Smith DC, McDermott DF, et al. Safety, activity, and immune correlates of anti-PD-1 antibody in cancer. N Engl J Med. 2012;366(26):2443-54.

36. Prieto PA, Yang JC, Sherry RM, Hughes MS, Kammula US, White DE, et al. CTLA-4 blockade with ipilimumab: long-term follow-up of 177 patients with metastatic melanoma. Clin Cancer Res. 2012;18(7):2039-47.

37. Saenger YM, Wolchok JD. The heterogeneity of the kinetics of response to ipilimumab in metastatic melanoma: patient cases. Cancer Immun. 2008;8:1.

38. Wolchok JD, Hoos A, O'Day S, Weber JS, Hamid O, Lebbé C, et al. Guidelines for the evaluation of immune therapy activity in solid tumors: immune-related response criteria. Clin Cancer Res. 2009;15(23):7412-20.
39. Ryan CJ, Smith MR, Fizazi K, Saad F, Mulders PF, Sternberg CN, Miller K, Logothetis CJ, Shore ND, Small EJ, Carles J, Flaig TW, Taplin ME, Higano CS, de Souza P, de Bono JS, Griffin TW, De Porre P, Yu MK, Park YC, Li J, Kheoh T, Naini V, Molina A, Rathkopf DE; COU-AA-302 Investigators. Abiraterone acetate plus prednisone versus placebo plus prednisone in chemotherapy-naive men with metastatic castration-resistant prostate cancer (COU-AA-302): final overall survival analysis of a randomised, double-blind, placebo-controlled phase 3 study. Lancet Oncol. 2015;16(2):152-60.

40. Beer TM, Armstrong AJ, Rathkopf DE, Loriot $Y$, Sternberg CN, Higano CS, Iversen P, Bhattacharya S, Carles J, Chowdhury S, Davis ID, de Bono JS, Evans CP, Fizazi K, Joshua AM, Kim CS, Kimura G, Mainwaring P, Mansbach H, Miller K, Noonberg SB, Perabo F, Phung D, Saad F, Scher HI, Taplin ME, Venner PM, Tombal B; PREVAIL Investigators. Enzalutamide in metastatic prostate cancer before chemotherapy. N Engl J Med. 2014;371(5):424-33.

41. Sweeney CJ, Chen YH, Carducci M, Liu G, Jarrard DF, Eisenberger M, et al. Chemohormonal Therapy in Metastatic Hormone-Sensitive Prostate Cancer N Engl J Med. 2015;373(8):737-46.

42. James ND, Sydes MR, Mason MD, Clarke NW, Dearlaney DP, Spears MR. Docetaxel and/or zoledronic acid for hormone-naïve prostate cancer: First overall survival results from STAMPEDE [abstract]. J Clin Oncol. 2015;33: (Suppl abstract 5001).

43. Parker C, Nilsson S, Heinrich D, Helle SI, O'Sullivan JM, Fosså SD, Chodacki A, Wiechno P, Logue J, Seke M, Widmark A, Johannessen DC, Hoskin P, Bottomley D, James ND, Solberg A, Syndikus I, Kliment J, Wedel S, Boehmer S, Dall'Oglio M, Franzén L, Coleman R, Vogelzang NJ, O'Bryan-Tear CG, Staudacher K, Garcia-Vargas J, Shan M, Bruland ØS, Sartor 0; ALSYMPCA Investigators. Alpha emitter radium-223 and survival in metastatic prostate cancer. N Engl J Med. 2013;369(3):213-23.

44. Cortes J, O'Shaughnessy J, Loesch D, Blum JL, Vahdat LT, Petrakova K, Chollet P, Manikas A, Diéras V, Delozier T, Vladimirov V, Cardoso F, Koh H, Bougnoux P, Dutcus CE, Seegobin S, Mir D, Meneses N, Wanders J, Twelves C; EMBRACE (Eisai Metastatic Breast Cancer Study Assessing Physician's Choice Versus E7389) investigators. Eribulin monotherapy versus treatment of physician's choice in patients with metastatic breast cancer (EMBRACE): a phase 3 open-label randomised study. Lancet. 2011;377(9769):914-23.

45. Durkee BY, Dian Y, Pollom EL, King MT, Dudley AS, Shaffer JL, et al. CostEffectiveness of Pertuzumab in Human Epidermal Growth Factor Receptor 2-Positive Metastatic Breast Cancer. J Clin Oncol. 2016;34(9):902-9. 